\title{
Rastin Swap Deposit (RSD): A Financial Account of Rastin Banking
}

\author{
Bijan Bidabad \\ B.A., M.Sc., Ph.D., Post-Doc. \\ Professor \\ Economics and Chief Islamic Banking Advisor \\ Bank Melli, Iran \\ E-mail:bijan@bidabad.com
}

\begin{abstract}
This paper introduces Rastin Swap Deposit account as a new banking deposit account which is interest-free and is based on Swap Contract in Rastin Banking. In this depositing by opening the deposit, the depositor is entitled to use an interest-free loan to the amount and duration that his resources have been being deposited and then return the money back to the bank. Depositor and bank agree that a combination of money and duration be selected in such a way that the products of amount and duration in both operations of depositing and loaning be the same. From the time of depositing to the first maturity (the date that depositor requests loan), the depositor is lender and bank is borrower; and from the time of the first maturity to second maturity (the date that depositor returns the money back to the bank) depositor is borrower and bank is a lender. Rastin Swap Deposit (RSD) can be issued in both local and foreign currencies.
\end{abstract}

Keywords: Rastin Swap Deposit, Rastin Swap Card, Rastin Swap Bond, Rastin Banking, Islamic Banking, Interest-Free Banking, Swap Contract

JEL: E43, E44, E52, E58, E62, E63

\section{Introduction}

A banking account is an agreement between a bank and a person (real/legal entity), whereby the bank agrees to hold money and/or other assets on behalf of the person, or institution. What the holder may do with those assets depends upon the nature of the account. In a checking account and a savings account, a bank holds money for the client and pays him a certain percent age in interest. This payment gives the bank the right to lend the money to other clients or invest it within the confines of law and banking regulation. However, the client has the right to withdraw the total amount of money on demand. In a brokerage account, a brokerage holds money and securities for the client and makes transactions with them at the client's request. In exchange, the brokerage charges commissions for the transactions. ${ }^{\mathrm{I}}$

The main debt items in non-usury banks' balance sheet are various deposits of customers, which private or public clients have deposited at the bank. Generally, Islamic bank's deposits can be categorized into Qard-ul-Hasanah and investment (time) deposits. Qard-ul-Hasanah deposits are cheap resources and include jari (current/checking) account, Pasandaz (saving) account which all of them are free of financial cost (payable interest) for the depositor. Another type of banking resources is investment (time) deposits which Islamic bank can use them on the base of profit and loss sharing (PLS), and bank as intermediate agent applies them in different investment projects, and the investment return will be paid to depositors according to their proportions and durations. As a rule, all Qard-ul-Hasanah deposits should be allocated to Qard-ul-Hasanah loans. Qard-ul-Hasanah (current and saving accounts both) and also short-term time-deposit accounts might also be connected to a banking debit card, and depositor can withdraw money by the card; though the Qard-ul-Hasanah current account holder also benefits from check services.

Certificate of Deposit (CD) as public or specific deposits is known as another financing instrument. The financing through CD was approved by the Central Bank of Iran (CBI) in 200I to encourage investors to make short-term deposit with transaction

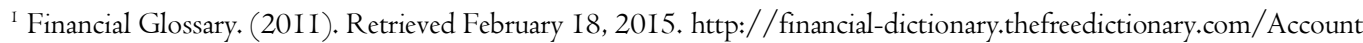


capability in secondary markets. Foreign exchange CD also was considered on the basis of the CBI's back up in 2007 a foreign exchange financing instrument for absorbing international resources particularly of Iranians resident at foreign countries.

This paper introduces Rastin Swap Deposit account as a new banking deposit which is interest-free and is based on Swap Contract ${ }^{2}$ in Rastin Banking ${ }^{3}$. In this type of depositing by opening the deposit, the depositor is entitled to use an interest-free loan to the amount and duration that his resources have been being deposited in the bank and then return the money back to the bank.

\section{Qard-ul-Hasanah in Quran}

By studying Quran verses, it is realized that Qard-ul-Hasanah is an ex gratia payment. In other words, Qard-ul-Hasanah in Quran mostly covers similar subjects as Takaful, and the interest-free loan is less concerned in this case. Qard-ul-Hasanah has been mentioned in different verses of the Quran, and all of them come right after the verses that emphasizing on Infaq $q^{4}$, Zakat ${ }^{5}$, Sadaqah ${ }^{6}$, or Qital. Therefore, we can genuinely interpret that Qard-ul-Hasanah is an ex gratia payment from one's property and when considering the literal meaning of "Qard' (loan), it means forfeiting one's body in the path of God, which is inherently good or "Hassan". In the verses of 244 of Surah of Al-Baqarah, He says: "who is he that will loan to Allah a beautiful loan, which Allah will double unto his credit and multiply many times? It is Allah that gives (you) want or plenty, and to him shall be your return." ${ }^{\prime}$ In verse 12 of Surah of Al-Ma'idah, it is said that: "I am with you if you perform As-Salat (Iqamat-as-Salat), and give Zakat, and believe in my messengers, and honor and assist them, and lend Allah a good loan (Qard)". In verses IO-I I of Surah of Al-Hadid, it is stated that: "And what is the matter with you that you do not spend in the cause of Allah? While to Allah belongs the heritage of the heavens and the earth. Not equal among you are those who spent and fought before the conquest (of Makkah) (and those among you who did so later). They are greater in degree than those who spent and fought afterward. But to all, Allah has promised the best (reward). And Allah is all-aware of what you do. Who is he that would lend to Allah a goodly loan, then (Allah) will increase it manifold to his credit (in repaying), and he will have a good reward"Io. In verse I8 of the same Surah, it is said that: "Indeed, those who give Sadaqat (i.e., Zakat and alms, etc.), men and women, and lend to Allah a goodly loan, it shall be increased manifold (to their credit), and theirs shall be an honorable good reward." II

According to the above-mentioned facts, it can be expressed that Qard-ul-Hasanah can be interpreted as the devotion of property and life, and it does not necessarily reflect the meaning of "loan". Maybe, using the word "Good Loan" will have less impact on the religious basis of Qard-ul-Hasanah as Quran states.

\section{Qard-ul-Hasanah Contract}

Qard-ul-Hasanah is amongst the binding possessory transactions, and it literally means to cut off. A person who cuts off a part of his/her property in order to lend it to another is called "Moqrid" or the lender, and the one who accepts this property is called "Moqtarid" or the borrower. According to Article 648 of the civil law of Iran, Qard is a transaction in which one of the parties grants a determined amount of his/her property to the other party and the other party shall return the exact amount at the same quality to the first party and if failing to do so, shall reimburse its money equivalent at the time of loaning. Therefore, the sums deposited in banks as Qard-ul-Hasanah are actually considered as the bank's own capital and the obligation of the bank regarding its customers as Moqtarid is to return the exact property. In fact, banks must return these sums as soon as the customer requires them.

The interpreted concepts about Qard-ul-Hasanah from Quran verses are different from its prevailing concept used nowadays. One of the usury-free banking operations is to provide Qard-ul-Hasanah loans. Usury-free banking regulation of Iran states:

\footnotetext{
${ }^{2}$ Bijan Bidabad, Azarang Amirostovar, Saeed Abdollahi, Mahmoud Allahyarifard, Eskandar Pordel, Maryam Heidari, Alireza Shafiei, Mohammad Ali Pourbehrouz, Draft of Rastin Banking Bill, Bank Melli Iran, 2012.

http://www.bidabad.com/doc/rastin-banking-bill.pdf

${ }^{3}$ Rastin Banking documents are accessible through: http://www.bidabad.com

${ }^{4}$ Infaq means charity, simply to please God without expecting any favor in return.

${ }^{5}$ Zakat is what purifies; it is the giving of a fixed portion of one's wealth to charity, generally to the poor and needy.

${ }^{6}$ Sadaqah is voluntary charity out of compassion, love, friendship (fraternity) or generosity.

${ }^{7}$ Qital is battle.
}

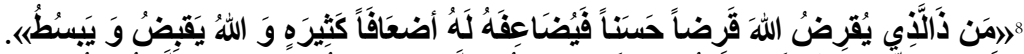

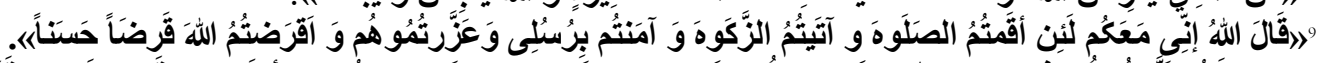

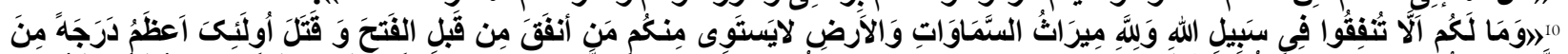

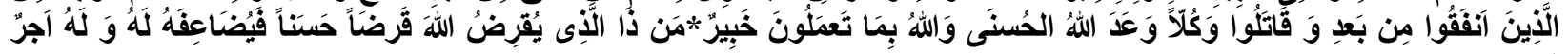
كَرِيُّن

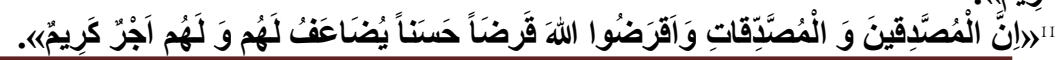
(7) (3) Copright O CC-BY-NC 2019, CRIBEB | IJBFR 
"Qard-ul-Hasanah is a transaction in which, the lender delivers a specific amount of his/her property to borrower and borrower will reimburse the lender with the same property or its price". Jurisprudents consider Qard-ul-Hasanah to be valid when the original property is returned to the owner, even though this definition is the same as the "loan" definition in the civil law. Unfortunately, in today's society, the loans accompanied with a surplus have become significantly prevailing, and as a result, the usury-free loan has been named Qard-ul-Hasanah.

\section{Rastin Swap Deposit (RSD)}

Rastin Swap Deposit (RSD) is a kind of banking account which is opened in Rastin Banking. Rastin Swap Deposit (RSD) has lots of similarities to Rastin Swap Bond (RSB) and Rastin Swap Card (RSC) ${ }^{12}$. In both Rastin Swap Deposit (RSD) and Rastin Swap Bonds (RSBs) depositing is done at first, and then loan occurs; as it is cleared by figures I.

By depositing in the bank in a Rastin Swap Deposit (RSD) account, the bank accepts that with respect to depositing a certain amount of money of depositor for certain time duration, (bank) is obliged to loan the same amount for the same duration to the depositor. They can also agree with a combination of amount and duration for both stages of depositing and lending be selected in such a way that multiplication of amount and duration for the money deposited and money lent be equal. At the first maturity, the depositor receives the money back, and the bank lends depositor an amount equivalent to the amount depositor had deposited for the same duration in the bank in his RSD account. After reaching the second maturity, the depositor will return the lent money to the bank.

Rastin Swap Deposit (RSD) account is opened under certain conditions. Accordingly, by depositing $\$ \mathrm{~A}$ with a duration of $\mathrm{N}$ months, the bank will be obliged to lend $\$ A$ interest-free loan for a period of $N$ months to the depositor. The depositor and bank agree on fixing combinations of $\$ \mathrm{~A}$ and $\mathrm{N}$ months so that the depositor can choose smaller, equal or larger than one ratios from $\$ A$ in proportion with $N$ months in such a way that the result of the amount of money multiplied by time, be equal to $\mathrm{A} \times \mathrm{N}$. For example, depositor instead of $\$ \mathrm{~A}$, can borrow $\$ \mathrm{~A} / 2$ for $2 \mathrm{~N}$ months at the $\mathrm{N}^{\text {th }}$ month, or $\$ \mathrm{~A} / 3$ for $3 \mathrm{~N}$ months at the $N^{\text {th }}$ month. Where, in all cases, the result will be equal to $A \times N$. That is: $(A / 2) \times(2 N)=(A / 3) \times(3 N)=A \times N$ or generally speaking; instead of $\$ \mathrm{~A}$, depositor receives $\$ \mathrm{~A} / \mathrm{k}$ for $\mathrm{k} \times \mathrm{N}$ months after the $\mathrm{N}$ months. The parameter $\mathrm{k}$ can be agreed upon mutually by the parties, or offered by the depositor. This procedure is depicted in figure $\mathrm{I}$.

Generally, RSD has two periods and two maturity dates. The first period is equal to $\mathrm{N}$ months from the depositing time to the first maturity, and the second period is from the first maturity date $(\mathrm{N})$ until the payback date of funds $(\mathrm{kN}+\mathrm{N})$ or second maturity date. The first maturity is when the depositor withdraws his deposit and bank is obliged to provide the loan equal to $\$ \mathrm{~A}$ for $\mathrm{N}$ months, or $\$ \mathrm{~A} / \mathrm{k}$ for $\mathrm{kN}$ months to the depositor. Therefore, the first maturity occurs at the end of $\mathrm{N}$ months. The second maturity is the end of the contract when the bank will receive back its funds after $\mathrm{kN}+\mathrm{N}$ months after depositing time.

The depositor is obliged to give the necessary guarantee or collateral to the bank to bring faith to fulfill his obligations when he borrows from the bank at the second stage. Type of pledge or guarantee is determined by the bank due to its understanding of the depositor's financial history and the amount of the loan. At the second maturity, guarantee or collateral of the depositor is released when the obligation is fulfilled.

This Rastin Swap Deposit is contracted upon Mubadalah (swap) contract ${ }^{13}$ between Mobadil (swapper) and Motebadil (swappee) in which the durations and substances of swaps are equal for first and second swaps. Mobadil (swapper) is the depositor and is creditor from Motebadil (bank) equal to the nominal value of the deposit, and Motebadil (bank) should pay this amount (badal) (swapped) to Mobadil (swapper/depositor) at first maturity. The bank (Motebadil) is obliged to lend the mobaadal (re-swapped) for the same amount and period as badal to mobadil (depositor). Bank can choose a combination of amount and duration that the multiplication of amount by the duration of mobaddal (re-swapped) be equal to that of badal (swapped). At the second maturity, mobadil(depositor) is committed to returning mobaddal (re-swapped) to motebadil(bank). ${ }^{I 4}$ No interest rate is involved in this deposit. The durations of swapped and re-swapped and interregnum duration are

\footnotetext{
${ }^{\text {I2 }}$ Bijan Bidabad, Rastin Swap Card, 2015, http://www.bidabad.com/doc/rsc-paper-en.pdf

${ }_{13}$ Bijan Bidabad, Azarang Amirostovar, Saeed Abdollahi, Mahmoud Allahyarifard, Eskandar Pordel, Maryam Heidari, Alireza Shafiei, Mohammad Ali Pourbehrouz, Draft of Rastin Banking Executive Regulation, Bank Melli Iran, 2012.

http://www.bidabad.com/doc/rastin-banking-regulation.pdf

${ }^{14}$ Bijan Bidabad, Azarang Amirostovar, Saeed Abdollahi, Mahmoud Allahyarifard, Eskandar Pordel, Maryam Heidari, Alireza Shafiei, Mohammad Ali Pourbehrouz, Draft of Rastin Banking Executive Regulation, Bank Melli Iran, 2012.

http://www.bidabad.com/doc/rastin-banking-regulation.pdf
} 
determined when the contract is signed. End of the Badal duration is called Badal (first) maturity, and the end of Mobaddal duration is called Mobaddal (second) maturity. Interregnum duration in Rastin Swap Deposit is the time interval between Badal maturity and the start of Mobaddal duration.

In case of nonfulfillment of obligations at second maturity, Mobadil(bank) after receiving Badal can hold the Mobaddal beside itself in such a way that the multiplication of Badal duration by the amount of Badal is equal to the same multiplication for the sum of Mobaddal duration plus delayed duration by Mobaddal amount.

Rastin Swap Deposit can be both issued in foreign currencies as well as local currency. In this connection, there is no significant difference between the two in local and foreign currencies except that the nominal amounts at both durations could be foreign exchange. In any case, the currency type of Baddal and Mobaddal should be the same. If the deposit is opened for the case of different currencies for Badal and Mobaddal, there would be no Riba skepticism in the transaction yet. But to ascertain the case both sides of the contracts commit that at the first maturity, rate of currency exchange be applied to convert Badal in first currency into Mobaddal in the second currency.

Regarding the fact that this deposit is not based upon participation and just swaps the money, it is not covered by regulations of the Rastin PLS Base system ${ }^{15}$ but uses its infrastructure and organization. ${ }^{16}$ The monetary and fiscal effects, as well as the economic effects of issuing Rastin Swap Deposit, are similar to Rastin Swap Bonds that have been discussed in other papers.

${ }^{17}$ Operational details of Rastin Swap Deposit (RSD) have been explained in Rastin Banking Bylaw ${ }^{18}$.

\footnotetext{
${ }^{15}$ Bijan Bidabad, Rastin Profit and Loss Sharing (PLS) Base System. Journal of Islamic Economics, Banking and Finance, pp. 32-57, Vol. 9 No. 4, Oct - Dec 2013.

http://ibtra.com/pdf/journal/v9_n4_article2.pdf

http://www.bidabad.com/doc/pls-base-en.pdf

${ }^{16}$ Bijan Bidabad, M. Safarzadeh and J. Aghabeigi, Organization of Profit and Loss Sharing (PLS) Banking in Bank Melli Iran. Bank Meli Iran, 20I I. http://www.bidabad.com/doc/PLS-organization.pdf

${ }^{17}$ See:

- Bijan Bidabad, Islamic Monetary Policy, 2013. http://www.bidabad.com/doc/islamic-monetary-policy-en.pdf

- Bidabad, Bijan, Mahmoud Allahyarifard. Usury-Free Bonds and Islamic Central Banking Monetary Instruments. 2010. http://www.bidabad.com/doc/Islamic-banking-bond-en.pdf

- Bidabad, Bijan, Abul Hassan, Ben Ali Mohamed Sami, Mahmoud Allahyarifard. Interest-Free Bonds and Central Banking Monetary Instruments. International Journal of Economics and Finance. Vol. 3, no. 3, Aug 20I I, pp.234-24I.

http://www.ccsenet.org/journal/index.php/ijef/article/download/II665/8300

- Bidabad, Bijan,Interest-Free Treasury Bonds (IFTB), 20II. http://www.bidabad.com/doc/interest-free-t-bond-en.pdf http://www.bidabad.com/doc/iftb-en.pptx

- Bidabad, Bijan, Interest-Free Treasury Bonds (IFTB), Islamic Finance and Legal Clarifications, 201 I.

http://www.bidabad.com/doc/interest-free-t-bond-feqhi-en.pdf

- Bidabad, Bijan, Abul Hassan, Ben Ali Mohamed Sami, Mahmoud Allahyarifard. Interest-Free Bonds Financial Innovation, A Monetary Instrument for Economy at Crisis. Journal of Economic Cooperation and Development (JECD). 32, I, 20II, 55-70.

http://www.sesric.org/jecd/jecd_articles/ARTI0I0220I-2.pdf

${ }^{18}$ Bijan Bidabad, Azarang Amirostovar, Saeed Abdollahi, Mahmoud Allahyarifard, Eskandar Pordel, Maryam Heidari, Alireza Shafiei, Mohammad Ali Pourbehrouz, Draft of Rastin Banking Executive Regulation, Bank Melli Iran, 2012.

http://www.bidabad.com/doc/rastin-banking-regulation.pdf
} 


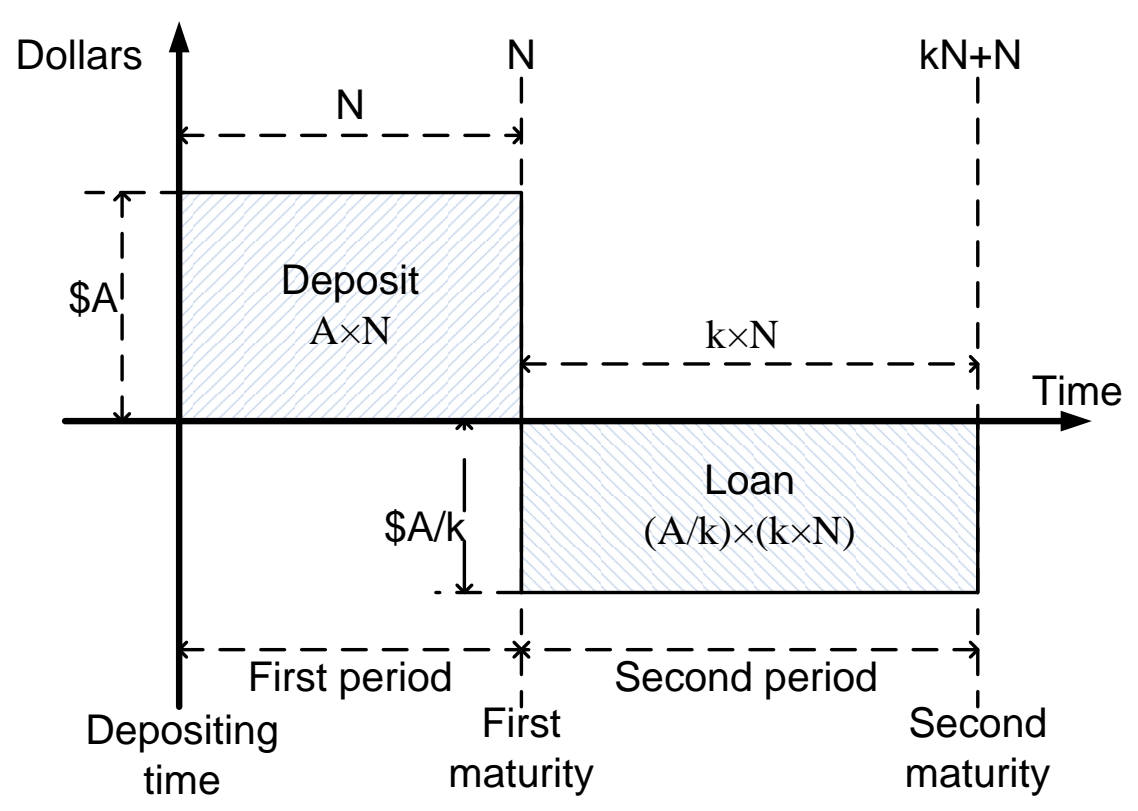

Figure I. Two-Phases Maturity of Rastin Swap Deposit (RSD)

\section{Sharia Allowances of Rastin Swap Deposit (RSD)}

Essentially, usury occurs in loans, and loans have two different kinds of consumption and investment loans. Investment loans result in profit/loss, and the loan itself is not for spending or consumption. Consumption loans are used for everyday life spending. ${ }^{19}$ Sharia prohibition reasoning mostly concern consumption loans ${ }^{20}$.

"Transaction usury" is defined as transacting a measurable commodity/money with a surplus amount of the same commodity/money. Because of the excessive amount paid to the other party; this transaction involves usury, and is prohibited by Sharia. In "transaction usury", transacting equal amount along a period is not considered, but transacting with an extra amount is at the focus of attention. That is why Rastin Swap Card does not enter into the domain of "usury transaction; because its financial activity is not based upon transaction of extra amount, just equal amounts are bartered along two periods, and creditor obtains no surplus.

In "loan usury", a person lends (money or commodity) and receives it back with a surplus. In "loan usury", the surplus has not necessarily the same type or quality of the original commodity and includes any kind of surplus. Rastin Swap Card is not "loan usury" as well.

The spiritual reference of the verses 278-28I of Surah of Baqarah: "Your capitals will be yours, you won't suppress and will not be suppressed" approves the correctness of Rastin Swap Card ${ }^{21}$. This is because according to "your capitals will be yours", the principal loan will be returned to the lender, and in order to prevent doing any oppression, or being oppressed "you won't suppress and will not be suppressed", he will receive loan in an equal amount of what he had lent, which exactly complies the meaning of this verse.

\footnotetext{
19 - Bidabad, Bijan, Economic-juristic analysis of usury in consumption and investment loans and contemporary jurisprudence shortages in exploring legislator commandments. Proceeding of the $2^{\text {nd }}$ International Islamic Banking Conference. Monash University of Malaysia. 9-IO September 2004. Reprinted in: National Interest, Journal of the Center for Strategic Research, Vol. 2, No. I, winter 2006, pp. 72-90. Tehran, Iran. http://www.bidabad.com/doc/reba-en.pdf

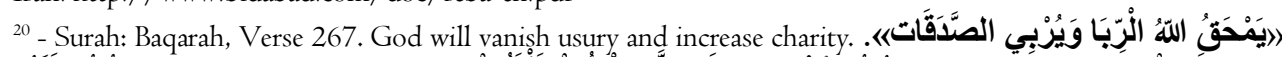

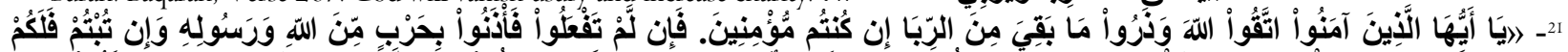

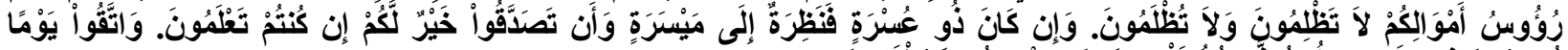

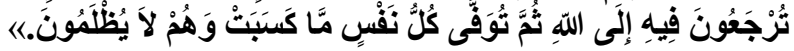

O! Believers, care about God; leave what is left through usury. But if you don't, you should know that you are fighting against God and his messengers; and if you repent, your capitals will be yours. You won't suppress and will not be suppressed. If your debtors are poor, give them time until they obtain money; and if you bestow, it will be much better for you if you understand. Beware of the day you return to God, and then whatever obtained, will be returned to everybody; and they will not be suppressed. 


\section{Legal Institution for Rastin Swap Deposit (RSD)}

Many of monetary and banking activities are regarded as new subjects in civil laws of many countries. Civil laws have not reckoned all transaction contracts and has just mentioned some evidence such as pure transaction contract, conditional transaction, forward deal, spot transaction, over the counter transaction, future (Salaf) and prepaid (Salam) purchase, irrevocable transaction, optional transaction, valuable metals transaction, unauthorized transaction and etc. Therefore, we will not be wrong if we consider RSD with its similarities to "transaction contract", while the possessory right is suspended during the period of contract.

Promissory contracts seem to be a solution for the legal framework for RSD. New "counter-loaned contract" in which two parties decide to deposit a specific asset with the other party for a same period, and also "counter-trust contract" can be defined in this regard. But, revocability of promissory contracts creates difficulty for application of "counter-loaned contract" and "counter-trust contract" and "donation against loan contract" with zero donations in applying for Rastin Swap Card ${ }^{22}$. In this connection, the application of "time-barter contract" is not meaningless. Accordingly, we define "time-barter contract" in which a party lends an asset to the other party, in order to receive the same asset from him in future without considering that one of them is assets and the other is its price. If we consider the loan contract without surplus, "time-loan contract" might also be defined. We may define "time-loan contract" according to which each party loans the possession of his own specific asset to the other and the other party will loan back the similar asset with similar quality and amount to him at maturity, and if he cannot render the same asset, he should pay its spot price at the time of contracting. In all of these frames, one deposits some asset with the other person, and he will pay back the same amount at the maturity without any surplus or privilege.

However, as a conclusion, Rastin Swap Card is contracted based upon Mubadalah (swap) contract. But without legislation of this contract as law, the Rastin Swap Card can be contracted based upon the principle of sovereignty of contracts that is well known in law.

\section{References}

Rastin Banking documents are accessible through http://www.bidabad.com

Bidabad, Bijan, Azarang Amirostovar, Saeed Abdollahi, Mahmoud Allahyarifard, Eskandar Pordel, Maryam Heidari, Alireza Shafiei, Mohammad Ali Pourbehrouz, Draft of Rastin Banking Bill, Bank Melli Iran, 2012. http://www.bidabad.com/doc/rastin-banking-bill.pdf

Bidabad, Bijan, Rastin Swap Card, 2015, http://www.bidabad.com/doc/rsc-paper-en.pdf

Bidabad, Bijan, Azarang Amirostovar, Saeed Abdollahi, Mahmoud Allahyarifard, Eskandar Pordel, Maryam Heidari, Alireza Shafiei, Mohammad Ali Pourbehrouz, Draft of Rastin Banking Executive Regulation, Bank Melli Iran, 2012. http://www.bidabad.com/doc/rastin-banking-regulation.pdf

Bidabad, Bijan, Rastin Profit and Loss Sharing (PLS) Base System. Journal of Islamic Economics, Banking and Finance, pp. 32 57, Vol. 9 No. 4, Oct - Dec 2013. http://ibtra.com/pdf/journal/v9_n4_article2.pdf http://www.bidabad.com/doc/pls-base-en.pdf

Bidabad, Bijan, M. Safarzadeh and J. Aghabeigi, Organization of Profit and Loss Sharing (PLS) Banking in Bank Melli Iran. Bank Meli Iran, 201 I. http://www.bidabad.com/doc/PLS-organization.pdf

Bidabad, Bijan, Rastin Certificate Market (RCM), Complementary System of Rastin Banking, 20I3. International Journal of Islamic Business \& Management, 3(I), 35-43, 2019. https://www.cribfb.com/journal/index.php/ijibm/article/view/260 http://www.bidabad.com/doc/rastin-bank-rem-en.pdf

Bidabad, Bijan, Islamic Monetary Policy, 2013. http://www.bidabad.com/doc/islamic-monetary-policy-en.pdf

Bidabad, Bijan, Mahmoud Allahyarifard. Usury-Free Bonds and Islamic Central Banking Monetary Instruments. 2010. http://www.bidabad.com/doc/Islamic-banking-bond-en.pdf

Bidabad, Bijan, Abul Hassan, Ben Ali Mohamed Sami, Mahmoud Allahyarifard. Interest-Free Bonds and Central Banking Monetary Instruments. International Journal of Economics and Finance. Vol. 3, no. 3, Aug 20II, pp.234-24I. http://www.ccsenet.org/journal/index.php/ijef/article/download/I I665/8300

Bidabad, Bijan,Interest-Free Treasury Bonds (IFTB), 2011. http://www.bidabad.com/doc/interest-free-t-bond-en.pdf

22 - Bidabad, Bijan, Legal analysis of Interest-Free Bonds http://www.bidabad.com/doc/legal-analysis-of-non-usury-bonds.pdf 
http://www.bidabad.com/doc/iftb-en.pptx

Bidabad, Bijan (2019) Interest-Free Treasury Bonds (IFTB), Islamic Finance and Legal Clarifications, 20I I. International Journal of Islamic Business \& Management, 3(I), 2I-29.

http://www.bidabad.com/doc/interest-free-t-bond-feqhi-en.pdf

https://www.cribfb.com/journal/index.php/ijibm/article/view/258/353

Bidabad, Bijan, Abul Hassan, Ben Ali Mohamed Sami, Mahmoud Allahyarifard. Interest-Free Bonds Financial Innovation, A Monetary Instrument for Economy at Crisis. Journal of Economic Cooperation and Development (JECD). 32, I, 20I I, 55-70.

http://www.sesric.org/jecd/jecd_articles/ARTI0I0220I-2.pdf

Bidabad, Bijan; Azarang Amirostovar, Saeed Abdollahi, Mahmoud Allahyarifard, Eskandar Pordel, Maryam Heidari, Alireza Shafiei, Mohammad Ali Pourbehrouz, Draft of Rastin Banking Executive Regulation, Bank Melli Iran, 2012. http://www.bidabad.com/doc/rastin-banking-regulation.pdf

Bidabad, Bijan, Economic-juristic analysis of usury in consumption and investment loans and contemporary jurisprudence shortages in exploring legislator commandments. Proceeding of the $2^{\text {nd }}$ International Islamic Banking Conference. The Monash University of Malaysia. 9-I0 September 2004. Reprinted in: National Interest, Journal of the Center for Strategic Research, Vol. 2, No. I, winter 2006, pp. 72-90. Tehran, Iran.

http://www.bidabad.com/doc/reba-en.pdf

Bidabad, Bijan, Legal analysis of Interest-Free Bonds http://www.bidabad.com/doc/legal-analysis-of-non-usury-bonds.pdf

Bidabad, Bijan. (2014). New Operational Islamic Banking System, Volume One, Theoretical Foundations, LAP Lambert Academic Publishing, OmniScriptum GmbH \& Co. KG, ISBN: 978-3-659-54463-7.

Bidabad, Bijan. (20I4). New Operational Islamic Banking System, Volume Two, Applicational Issues, LAP Lambert Academic Publishing, OmniScriptum GmbH \& Co. KG, ISBN: 978-3-659-55210-6.

Bidabad, Bijan (2018), General Regulatory Framework in Rastin Profit and Loss Sharing Banking (Part I-Operational Context). Journal of Business and Finance in Emerging Markets, JBFEM, [S.1.], v. I, n. I, p. I I -26, May. ISSN 2580-5568. https://doi.org/I0.32770/jbfem.volI I I-26 http://www.bidabad.com/doc/rastin-regulatory-en-I.pdf

Bidabad, Bijan (2018), General Regulatory Framework in Rastin Profit and Loss Sharing Banking (Part II-Legal Groundwork). Journal of Business and Finance in Emerging Markets, JBFEM, JBFEM, [S.1.], v. I, n. 2, p. I09-I26, Nov. ISSN 25805568.

https://doi.org/I0.32770/jbfem.voll I09-I26 http://www.bidabad.com/doc/rastin-regulatory-en-II.pdf

Bidabad, Bijan (2019), General Regulatory Framework in Rastin Profit and Loss Sharing Banking (Part III-Auxiliary Provisions). Journal of Business and Finance in Emerging Markets, JBFEM, May, Vol 2, No. I, pp. 5I -65. ISSN 25805568.

https://doi.org/I0.32770/jbfem.vol25I-66 http://www.bidabad.com/doc/rastin-regulatory-en-III.pdf

Financial Glossary. (2011). Retrieved February I8, 2015.

http://financial-dictionary.thefreedictionary.com/Account

\section{Copyrights}

Copyright for this article is retained by the author(s), with first publication rights granted to the journal. This is an open-access article distributed under the terms and conditions of the Creative Commons Attribution license (http://creativecommons.org/licenses/by/4.0/). 